\title{
Molekularna patogeneza przewlekłej białaczki limfocytowej
}

\section{Molecular pathogenesis of chronic lymphocytic leukemia}

\author{
Emilia Białopiotrowicz, Przemysław Juszczyński \\ Zakład Hematologii Eksperymentalnej, Instytut Hematologii i Transfuzjologii, Warszawa
}

\begin{abstract}
Streszczenie
Przewlekta biataczka limfocytowa (CLL) to najczestszy typ biataczki u osób dorostych, charakteryzujacy sie nagromadzeniem dojrzatych limfocytów B we krwi obwodowej, szpiku kostnym i tkankach limfatycznych. Kliniczny przebieg CLL jest zróżnicowany i obejmuje spektrum przypadków od takich o powolnym, wieloletnim przebiegu po przypadki agresywne, w których nowotwór rozwija sie gwattownie $i$ kończy zgonem chorego w krótkim czasie. Zastosowanie nowoczesnych technik biologii molekularnej ujawnito znaczna heterogenność genetyczna i epigenetyczna wśród chorych na CLL oraz pozwolito wytypować mutacje somatyczne o istotnym znaczeniu rokowniczym. Zarówno genom, jak i epigenom CLL podlegaja dynamicznym zmianom w trakcie przebiegu choroby wskutek ewolucji klonalnej, która prowadzi do selekcji i ekspansji klonów komórek biataczkowych o najwyzszym potencjale dostosowawczym. W niniejszej pracy omówiono najwazniejsze aspekty molekularnej patogenezy CLL, $w$ tym role zaburzen genetycznych $i$ epigenetycznych, sygnatu od receptora B-komórkowego oraz wplyw mikrośrodowiska. Postęy w zakresie zrozumienia biologii CLL przyczynia sie do opracowania lepszego systemu prognozowania oraz umoziliwia bardziej spersonalizowane leczenie tej choroby w przysztości.
\end{abstract}

Słowa kluczowe: przewlekła białaczka limfocytowa, patogeneza, genom, epigenom, mikrośrodowisko, architektura klonalna, ewolucja klonalna

Hematologia 2016; 7, 4: 273-286

\begin{abstract}
Chronic lymphocytic leukemia (CLL) is the most common type of adult leukemia, characterized by accumulation of mature but functionally incompetent clonal B lymphocytes in peripheral blood, bone marrow and lymphoid tissues. The clinical course of CLL varies from patients with indolent, stable disease to those with aggressive leukemia who succumb to their disease in a short time. The use of novel molecular biology techniques revealed genetic and epigenetic heterogeneity among CLL patients and allowed to define novel somatic mutations of prognostic value. The CLL genome and epigenome undergo dynamic changes during disease course due to clonal evolution, which leads to selection and expansion of leukemic clones with the highest survival potential. This review focuses on the key aspects of CLL molecular pathogenesis including genetic and epigenetic alterations, $B$-cell signaling and the role of tumor microenvironment. Progress in the understanding of CLL biology will help to develop more accurate prognostication models and enable more personalized patient treatment in the future.
\end{abstract}

Key words: chronic lymphocytic leukemia, pathogenesis, genome, epigenome, microenvironment, clonal architecture, clonal evolution

Hematologia 2016; 7, 4: 273-286

Adres do korespondencji: Przemysław Juszczyński, Zakład Hematologii Eksperymentalnej, Instytut Hematologii i Transfuzjologii, tel. 223496 517, 223496 518, 223496 305, ul. Indiry Gandhi 14, 02-776, Warszawa, e-mail: pjuszczynski@ihit.waw.pl 


\section{Wprowadzenie}

Przewlekła białaczka limfocytowa (CLL, chronic lymphocytic leukemia) jest najczęstszym typem nowotworu układu chłonnego w Europie i Ameryce Północnej. Występuje głównie u osób po 70. roku życia, a jej częstość jest większa u mężczyzn niż u kobiet [1]. Nie zaobserwowano istotnego związku między zapadalnością na CLL a ekspozycją na karcynogeny czy promieniowanie jonizujące [2]. W 5-10\% przypadków CLL stwierdza się rodzinne występowanie wcześniejszych przypadków tej choroby lub innych typów chłoniaków nie-Hodgkina [3]. Rozwój CLL jest poprzedzony okresem monoklonalnej limfocytozy B-komórkowej (MBL, monoclonal B-cell lymphocytosis) charakteryzującej się obecnością komórek CLL-podobnych we krwi obwodowej chorego, który nie wykazuje żadnych innych objawów chorobowych [4]. Rocznie 1-3\% przypadków MBL transformuje do CLL [4].

Charakterystyczną cechą CLL jest akumulacja dojrzałych, lecz funkcjonalnie niekompetentnych limfocytów B we krwi obwodowej, szpiku kostnym oraz limfatycznych i pozalimfatycznych narządach wewnętrznych. Rozpoznania CLL dokonuje się w przypadku obecności co najmniej 5000 klonalnych limfocytów B w mikrolitrze krwi obwodowej utrzymujących się przez ponad 3 miesiące [5]. Limfocyty we krwi to głównie komórki w fazie spoczynkowej $\left(\mathrm{G}_{0}\right)$ o niskim indeksie proliferacyjnym. Za nagromadzenie nieprawidłowych limfocytów odpowiadają małe frakcje aktywnie proliferujących komórek zlokalizowanych w ośrodkach namnażania znajdujących się w węzłach chłonnych oraz szpiku kostnym [6]. Wskutek podziałów komórkowych frakcja ta powiększa się nawet o $2 \%$ każdego dnia [7].

W ostatnich dwóch dekadach dokonał się bardzo istotny postęp w zrozumieniu biologii i patogenezy CLL. Fundamentalnym czynnikiem różnicującym podstawowe biologiczno-kliniczne podtypy tej choroby jest obecność lub brak hipermutacji somatycznej rejonu zmiennego ciężkiego łańcucha immunoglobulin (IGHV, immunoglobulin heavy chain variable) [8]. Około $60 \%$ wszystkich przypadków CLL cechuje się występowaniem mutacji somatycznych w rejonie $I G H V$ (M-CLL, $m u$ tated $C L L$ ), natomiast u pozostałych $40 \%$ chorych stwierdza się co najmniej 98-procentową zgodność sekwencji $I G H V$ z linią zarodkową (U-CLL, unmutated $C L L)$. Chorzy z niezmutowanym regionem $I G H V$ (U-CLL) charakteryzują się wyższą ekspresją CD38 (cluster of differentiation 38), ZAP70 (70 kDa zeta-associated protein), większą aktywnością receptora B-komórkowego (BCR, B-cell receptor) oraz niestabilnością genomową w stosunku do osób z fenotypem M-CLL [9]. U chorych na U-CLL rokowanie jest gorsze niż u chorych na M-CLL [9].

Odzwierciedleniem biologicznej heterogenności CLL jest zróżnicowany przebieg kliniczny obejmujący przypadki od tych o powolnym przebiegu i długości życia zbliżonej do populacji ogólnej, po takie, w których nowotwór rozwija się gwałtownie i w krótkim czasie powoduje zgon chorego [9]. Do istotnych czynników prognostycznych w CLL zalicza się między innymi stan zaawansowania klinicznego oparty na klasyfikacji Rai lub/i Bineta, osoczowe stężenia $\beta_{2}$-mikroglobuliny, dehydrogenazy mleczanowej (LDH, lactate dehydrogenase) i kinazy tymidyny oraz poziom ekspresji CD38 i ZAP70. Wraz ze zrozumieniem molekularnej patogenezy CLL i biologicznych podstaw tej choroby zdefiniowano wiele nowych markerów genetycznych i komórkowych (aberracje genomowe, mutacje genetyczne, zaburzenia epigenetyczne oraz deregulacje ścieżek sygnałowych) [8].

\section{Pochodzenie przewlekłej białaczki limfocytowej}

Komórki CLL charakteryzują się ekspresją markerów powierzchniowych CD19, CD5, CD23, niską ekspresją CD20 oraz niskim poziomem immunoglobulin powierzchniowych (sIg, surface immunoglobulin), co pozwala na zaklasyfikowanie CLL jako nowotworu dojrzałych limfocytów B i odróżnienie od innych nowotworów pochodzenia B-komórkowego [10]. Ustalenie prawidłowego odpowiednika komórek CLL jest utrudnione istnieniem dwóch podtypów CLL różniących się stanem mutacji $I G H V$. Brak mutacji somatycznych w IGHV sugeruje pochodzenie komórek U-CLL od naiwnych limfocytów $\mathrm{B}$, natomiast zmutowane regiony $I G H V$ w przypadkach M-CLL wskazuja na pochodzenie $z$ limfocytów germinalnych. Pod względem profilu ekspresji genów (transkryptomu) oraz profilu metylacji DNA (metylomu) komórki CLL są najbardziej zbliżone do dojrzałych komórek B o immunofenotypie CD5+ [11-13]. Dlatego sugeruje się, że zależnie od stanu mutacji $I G H V$ komórki CLL pochodzą od różnych subpopulacji komórek CD5+ (ryc. 1). Komórki białaczkowe $z$ niezmutowanymi genami $I G H V$ (przypadki U-CLL) wywodzą się $z$ naiwnych pregerminalnych komórek CD5+ lub z komórek CD5+, które przeszły dojrzewanie pozagerminalne, zaś komórki ze zmutowanymi genami $I G H V$ pochodzą $z$ subpopulacji postgerminalnych limfocytów CD5+CD27+ [11, 12]. Odmienne pochodzenie komórek białaczko- 


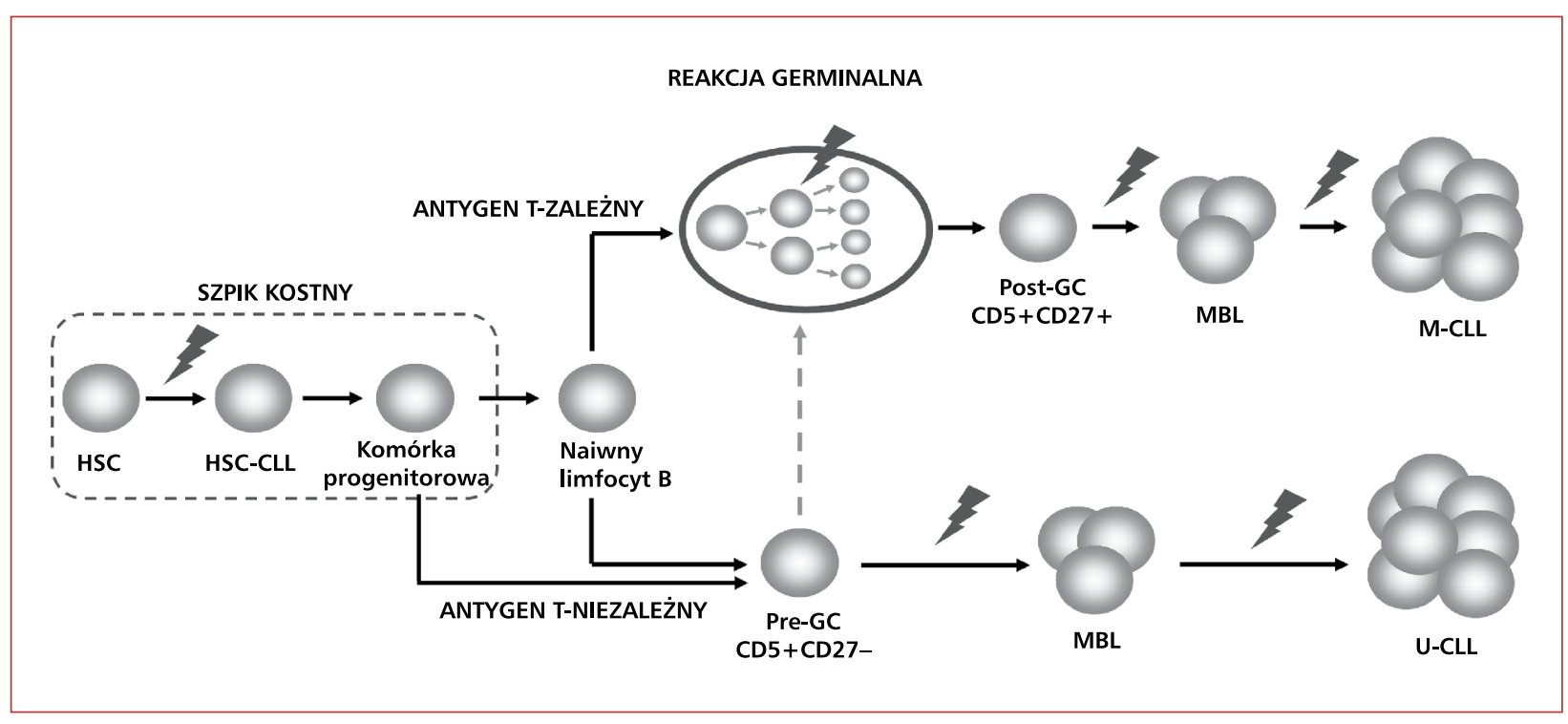

Rycina 1. Pochodzenie komórek przewlekłej białaczki limfocytowej (CLL) ze zmutowanymi (M-CLL) i niezmutowanymi (U-CLL) genami IGHV; - zmiany genetyczne/epigenetyczne; HSC — krwiotwórcza komórka macierzysta; HSC-CLL - HSC ze zmianami predysponującymi do rozwoju CLL; pre-GC — komórka pregerminalna; post-GC — komórka postgerminalna; MBL — monoklonalna limfocytoza B-komórkowa

Figure 1. The origin of chronic lymphocytic leukemia (CLL) cells with mutated (M-CLL) and unmutated (U-CLL)/GHV gene; - genetic/epigenetic changes; HSC — hematopoietic stem cell; HSC-CLL — HSC with alterations predisposing to CLL development; pre-GC - pre-germinal center cell; post-GC - post-germinal center cell; $\mathrm{MBL}$ - monoclonal B-cell lymphocytosis

wych podtypów U-CLL i M-CLL odzwierciedla ich różny fenotyp biologiczno-kliniczny (ryc. 1) [9].

Przewlekła białaczka limfocytowa jest nowotworem wywodzącym się $z$ dojrzałych limfocytów $\mathrm{B}$, ale istnieją dowody na to, że pierwsze zmiany genetyczne i epigenetyczne predysponujące do rozwoju tej choroby mogą zachodzić jeszcze w krwiotwórczych komórkach macierzystych (HSC, hematopoietic stem cells) (ryc. 1). Przeszczepienie HSC od chorych na CLL immunoniekompetentnym myszom powoduje $u$ tych zwierząt klonalną proliferację limfocytów B [14]. Zjawiska tego nie zaobserwowano $\mathrm{w}$ przypadku przeszczepiania ludzkich komórek CLL (CD5+). W dodatku u około $10 \%$ populacji chorych na CLL obecność mutacji typowych dla tej choroby (obejmujące geny NFKBIE, EGR2, BRAF, NOTCH1 i SF3B1) stwierdza się w komórkach progenitorowych CD34+ [15].

\section{Rola antygenu i sygnału od receptora B-komórkowego}

Receptor B-komórkowy (BCR, B-cell receptor) to kompleks białek, w skład którego wchodzą antygenowo specyficzne sIg oraz heterodimery Ig $\alpha$ i $\operatorname{Ig} \beta$ (CD79A i CD79B). Związanie antygenu do sIg powoduje aktywację kinaz rodziny Src (LYN), które fosforylują motywy ITAM (immunoreceptor tyrosine-based activation motifs) cytoplazmatycznych ogonów peptydowych $\operatorname{Ig} \alpha$ i $\operatorname{Ig} \beta$. Fosforylacja motywów ITAM pozwala na dokowanie kinazy SYK i uruchomienie SYK-zależnej transdukcji sygna$\mathrm{lu}$ - aktywację kinazy Brutona (BTK, Bruton's tyrosine kinase) oraz kinazy 3-fosfatydyloinozytolu (PI3K, phosphoinositide 3-kinase). W kolejnych etapach dochodzi do aktywacji fosfolipazy C- $\gamma 2$ (PLC- $\gamma 2$, phospholipase $C-\gamma 2$ ), szlaków sygnałowych kinazy białkowej C (PKC, protein kinase C), czynnika jądrowego $\kappa \mathrm{B}(\mathrm{NF} \kappa \mathrm{B}$, nuclear factor kappa-light-chain-enhancer of activated $B$ cells) i kinaz aktywowanych mitogenami (MAPK, mitogen-activated protein kinases) oraz następuje zmiana stężenia jonów wapnia w komórce [16]. Ostateczną konsekwencją aktywacji BCR przez antygen jest zmiana profilu ekspresji genów [16]. Ponadto BCR wykazuje pewną aktywność bazalną przy braku związania antygenu. Niezależna od ligandu, czyli toniczna aktywność BCR chroni limfocyt B przed włączeniem spontanicznej apoptozy [16].

Komórki CLL znajdujące się w węzłach chłonnych cechuje większa aktywność BCR niż komórek 
CLL pobranych $z$ krwi obwodowej, co wskazuje na rolę mikrośrodowiska węzłowego i potencjalną rolę antygenów w wyzwalaniu tego sygnału [17, 18]. Na rolę stymulacji antygenowej wskazuje również ukierunkowany repertuar genów immunoglobulinowych wśród populacji chorych na CLL [19]. U około $30 \%$ chorych, w tym częściej u osób z niezmutowanymi genami $I G H V$, występują tak zwane stereotypowe BCR charakteryzujące się strukturalnymi podobieństwami $\mathrm{w}$ obrębie regionów determinujących komplementarność (CDR, complementarity-determining regions). Zidentyfikowano około 200 podtypów stereotypowych BCR, z których obecność 19 powtarza się u $10 \%$ populacji chorych [19]. Receptory B-komórkowe chorych na U-CLL i M-CLL różnią się reaktywnością. W przypadku U-CLL receptory mają charakter polii autoreaktywny o słabym powinowactwie. Dlatego przypuszcza się, że w patogenezę U-CLL są zaangażowane autoantygeny $\mathrm{i}$ antygeny pochodzenia zewnętrznego, takie jak łańcuch ciężki miozyny MYHIIA (non-muscle myosin heavy chain IIA), wimentyna, kofilina 1, łańcuch ciężki IgG, jednoniciowy i dwuniciowy DNA, antygeny pochodzenia bakteryjnego (np. lipopolisacharyd) oraz antygeny wirusa zapalenia wątroby typu C $[20,21]$. W przeciwieństwie do podtypu U-CLL receptory u chorych na M-CLL mają charakter mono- i oligoreaktywny i rozpoznają węższy repertuar antygenów, takich jak $\beta$-(1,6)-glukany pochodzenia drożdżowego czy łańcuchy ciężkie czynnika reumatoidalnego [22]. Obok aktywacji zależnej od antygenu BCR chorych może ulegać aktywacji autonomicznej poprzez rozpoznawanie epitopów w obrębie łańcucha ciężkiego trzeciego regionu determinującego komplementarność (HCDR3, heavy chain of the third complementarity-determining region) [23].

Ze względu na istotną rolę biologiczną sygnal BCR stanowi atrakcyjny cel terapeutyczny w CLL. Ibrutynib (inhibitor BTK) oraz idelalizyb (inhibitor izoformy $\delta$ kinazy PI3K) zostały zarejestrowane w 2014 roku przez Europejską Agencję Leków (EMA, European Medicines Agency) do leczenia opornej/nawrotowej postaci CLL oraz jako leczenie pierwszej linii u chorych $z$ delecją chromosomu 17 (del17p). Nowe inhibitory BTK (ACP-196, ONO-4059), PI3K (duwalizyb, pilaralizyb, ACP-319) oraz SYK (fosfamatynib, GS-9973, PRT-2070) są obecnie w fazie badań klinicznych [24].

\section{Genomowa architektura CLL}

W CLL wskaźnik częstości mutacji wynosi 0,9/1000 000 par zasad, co czyni genom CLL relatywnie stabilnym $\mathrm{w}$ stosunku do genomu nowotworów narządów litych oraz innych nowotworów układu chłonnego [25]. Występowanie nieprawidłowości genomowych stanowi jednak ważny wskaźnik rokowniczy oraz istotny parametr pomagający monitorować skuteczność leczenia. Obecność aberracji cytogenetycznych stwierdza się u ponad $80 \%$ chorych. Najczęstsze aberracje chromosomowe spotykane w CLL to delecje 13q14 (50-60\%), 11q22-23 (12-18\%), 17p13 (5-50\%) oraz trisomia chromosomu 12 (ok. 15\%) [26, 27].

\section{Delecja 13q14}

Delecja 13q14 często występuje jako jedyna aberracja chromosomowa, co sugeruje jej rolę na wczesnych etapach patogenezy [28]. W 80\% przypadków del13q14 pojawia się monoallelicznie, częściej u chorych ze zmutowanym regionem $I G H V$ (M-CLL). Minimalny region ulegający delecji obejmuje geny DLEU2 (deleted in lymphocytic leukemia 2), DLEU1 oraz czasami DLEU7. Gen DLEU2 koduje krótkie jednoniciowe cząsteczki RNA (mikro-RNA), mir-15a i mir-16-1, które hamują ekspresję genów napędzających proliferację limfocytu B (BCL2, CCND1, CCND3, CDK6) [29]. Gen $D L E U 1$, podobnie jak DLEU2, koduje RNA o charakterze regulatorowym. $Z$ kolei produktem DLEU7 jest białko będące negatywnym regulatorem transkrypcji zależnej od $\mathrm{NF} \kappa \mathrm{B}$ i czynnika jądrowego aktywowanych komórek T (NFAT, nuclear factor of activated $T$ cells) [30]. Obniżoną ekspresję genów $D L E U$ w stosunku do osób zdrowych stwierdza się także u chorych bez del13q14, co sugeruje istnienie dodatkowych mechanizmów regulacji, które ulegają zaburzeniu w CLL [29]. Obecność del13q14 jest $z$ reguły markerem dobrego rokowania. Wyjątek stanowią przypadki, w których delecja obejmuje również gen supresora nowotworów RB1 (retinoblastoma 1) [31].

\section{Delecja 11q22-23}

Delecja 11q22-23 pojawia się częściej u chorych $z$ niezmutowaną konfiguracją genów $I G H V$ (U-CLL) i obejmuje gen ATM (ataxia-telangiectasia mutated), który koduje białko biorące udział w naprawie uszkodzeń DNA. Kinaza ATM powoduje zahamowanie cyklu komórkowego i uruchomienie mechanizmów naprawczych lub indukcję apoptozy [32]. W większości przypadków del11q22-23 pojawia się monoallelicznie, jednak u ponad $1 / 3$ chorych w drugiej kopii genu obserwuje się obecność mutacji somatycznych [33]. Chorzy z inaktywacją $A T M$ cechują się większą niestabilnością genomową, która sprzyja szybszej progresji choroby oraz che- 
miooporności [34]. Czasami delecja 11q nie narusza genu ATM, tylko gen BIRC3 (baculoviral IAP repeat containing 3 ), którego produkt jest negatywnym regulatorem ścieżki sygnałowej $\mathrm{NF} \kappa \mathrm{B}$ [35].

\section{Trisomia chromosomu 12}

Trisomia chromosomu 12 występuje ze zbliżoną częstością $15 \%$ niezależnie od stanu mutacji $I G H V$. Molekularne konsekwencje tego defektu pozostają niejasne, choć patogenetyczną rolę tej aberracji przypisuje się aktywacji sygnału zależnego od integryn, NOTCH1 lub zwiększeniu liczby kopii genu $M D M 2$, będącego negatywnym regulatorem p53 i ligazą E3 ubikwityny dla tego białka [36]. U chorych $z$ trisomią +12 obserwuje się częstsze przypadki rozwoju wtórnych nowotworów i progresję CLL do agresywnego chłoniaka (zespół Richtera) [37]. Zgodnie $z$ tymi obserwacjami a $\dot{z}$ u 1/3 osób z transformacją Richtera stwierdza się obecność trisomii chromosomu 12 [38].

\section{Delecja 17p13}

Delecja 17p13 pojawia się częściej u chorych $\mathrm{z}$ niezmutowanym rejonem $I G H V$ i obejmuje gen TP53, który koduje czynnik transkrypcyjny o właściwościach supresora nowotworowego. Białko p53 aktywuje mechanizmy naprawy DNA lub indukuje apoptozę w zależności od skali uszkodzeń [39]. Delecja $17 \mathrm{p} 13$ ma przeważnie charakter monoalleliczny, choć w ponad $80 \%$ przypadków drugi allel TP53 ulega inaktywacji wskutek mutacji somatycznych. Przypadki z del17p13 lub/i mutacją somatyczną w TP53 cechują niestabilny genom oraz złe rokowanie [40]. Chorzy z niefunkcjonalnym genem TP53 wykazują oporność na terapeutyki, które uruchamiają mechanizmy śmierci komórkowej zależne od p53, w tym chemioterapeutyki uszkadzające DNA [41]. Dlatego rekomenduje się rutynowe badanie chorych ze wskazaniem do leczenia pod kątem mutacji/delecji TP53 w celu doboru terapeutyków, które będą prowadzić do śmierci komórek białaczkowych na drodze mechanizmu p53-niezależnego [42]. Do związków takich należą zarejestrowane do leczenia inhibitory szlaku B-komórkowego (ibrutynib, idelalizyb) i antyapoptotycznego białka BCL2 (wenetoklaks) oraz intensywnie badane $\mathrm{w}$ ostatnich latach $\mathrm{w}$ obszarze przedklinicznym inhibitory kinaz PIM [43-46].

\section{Architektura mutacji somatycznych w CLL}

Rozwój technik sekwencjonowania nowej generacji (NGS, next generation sequencing) ujawnił znaczącą heterogenność genomu CLL pod kątem mutacji somatycznych. Zaledwie w kilku genach (NOTCH1, SF3B1, BIRC3, MYD88) mutacje somatyczne pojawiają się z częstością 5-10\%, zdecydowana większość mutacji występuje z częstością 2-5\% [47]. Mimo różnorodności mutacji somatycznych w CLL geny, których dotyczą te zmiany, można przyporządkować do kilku szlaków sygnałowych lub procesów komórkowych, takich jak szlaki sygnałowe BCR (BTK, CD79) i RAS-MAPK-ERK (BRAF, NRAS, KRAS, MAP2K1), odpowiedź na uszkodzenia DNA (TP53, ATM), procesowanie mRNA (SF3B1, XPO1), modyfikacje chromatyny (HIST1H1E, CHD2, ZMYM3), szlaki sygnałowe WNT i NOTCH1, oraz odpowiedź prozapalna (MYD88) (ryc. 2). Częstość mutacji $\mathrm{w}$ genach związanych $z$ wymienionymi procesami komórkowymi/szlakami sygnałowymi różni się zależnie od stanu mutacji $I G H V$. Mutacje w genach szlaku NOTCH1 (NOTCH1, FBXW7), genach związanych $z$ procesowaniem i transportem RNA (SF3B1, U2AF2, SFRS1, XPO1, DDX3X) oraz genach związanych $z$ naprawą DNA (ATM, TP53, POT1) występują $z$ większą częstością u chorych $\mathrm{Z}$ niezmutowaną konfiguracją $I G H V$. Z kolei mutacje $\mathrm{w}$ genach związanych $\mathrm{z}$ odpowiedzią zapalną (MYD88, TLR2, MAPK1) pojawiają się $\mathrm{z}$ większą częstością u chorych ze zmutowanymi genami IGHV [47-49]. Różnice w zakresie częstości mutacji $\mathrm{w}$ genach związanych $\mathrm{z}$ określonymi procesami komórkowymi mogą tłumaczyć różnice biologiczne między U-CLL i M-CLL. Poniżej omówiono konsekwencje najczęściej występujących w CLL mutacji somatycznych.

\section{Mutacje NOTCH1}

Mutacje w NOTCH1 występują u $10 \%$ nowo zdiagnozowanych chorych, pojawiają się częściej u chorych z niezmutowanymi łańcuchami $I G H V$ i w $40 \%$ przypadków współwystępują z trisomią chromosomu 12 [50]. Gen NOTCH1 koduje receptor błonowy, który po związaniu z ligandem ulega proteolitycznemu cięciu. Uwolniony wewnątrzkomórkowy fragment NOTCH1 (ICN, intracellular NOTCH1) ulega translokacji do jądra, gdzie pełni rolę regulatora transkrypcji (ryc. 2). Większość mutacji w NOTCH1 uszkadza C-końcową domenę PEST, co w konsekwencji powoduje powstanie krótszego białka pozbawionego sygnału rozpoznawalnego przez ligazę ubikwityny FBXW7 (F-box and $W D$ repeat containing protein 7$). \mathrm{W}$ efekcie białko NOTCH1 z uszkodzoną domeną PEST charakteryzuje się zwiększoną stabilnością. Mutacja (c.7544_7545delCT) stanowi 80\% mutacji NOTCH1 w ČLL i może zostać wykryta metodą 


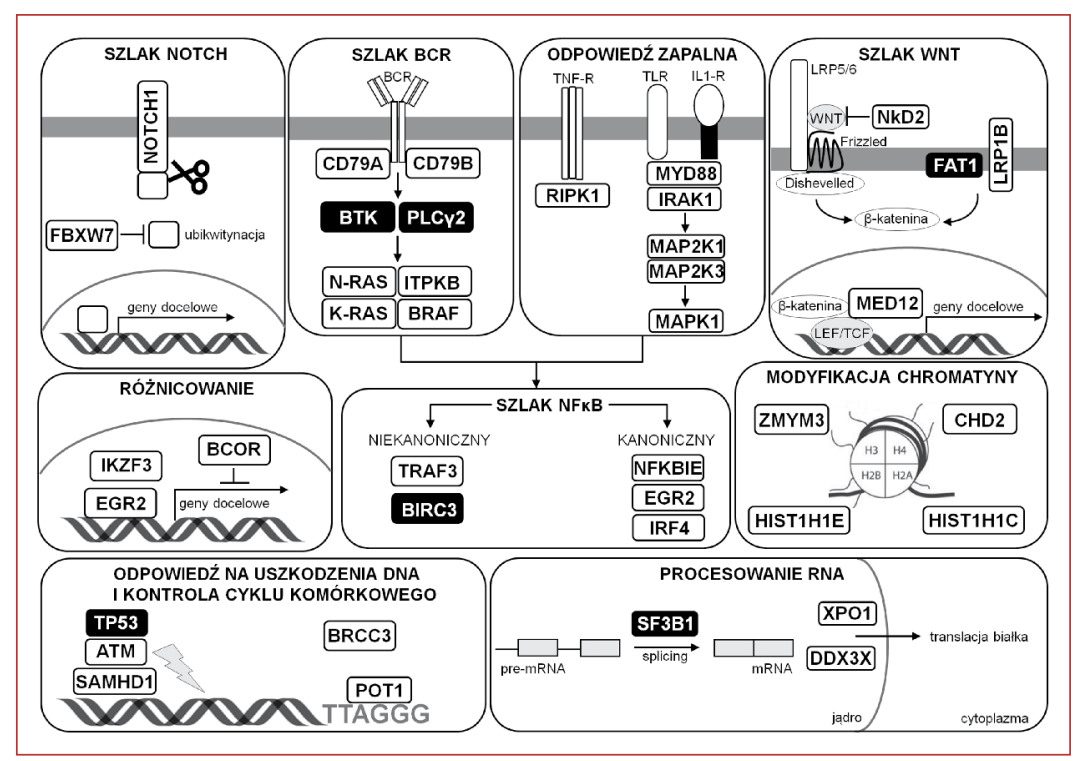

Rycina 2. Zaburzenia szlaków sygnałowych w przewlekłej białaczce limfocytowej (CLL). W kwadratowych ramkach oznaczono mutacje somatyczne typowe dla CLL. Na czarnym tle wyróżniono mutacje typowe dla przypadków opornych na leczenie lub z nawrotem choroby; BCR — receptor B-komórkowy; BTK — kinaza Brutona; PLC- $\gamma 2$ - fosfolipaza C- $\gamma 2$; TNF-R — receptor czynnika martwicy nowotworów; TCR — receptor T-komórkowy; TLR - receptor Toll-podobny; IL-1R — interleukina 1R; MAPK — kinazy aktywowane mitogenami; LEF — czynnik wzmacniający leukocyty; TCF — czynnik specyficzny dla komórek T; NF $\kappa$ B - czynnik jądrowy $\kappa \mathrm{B}$; pre-mRNA - prekursorowe matrycowe RNA; mRNA — matrycowe RNA

Figure 2. Altered signaling pathways in chronic lymphocytic leukemia (CLL). Somatic mutations typical for CLL are presented in rectangles. Mutations typical for refractory/relapsed cases are marked in black rectangles; BCR - B-cell receptor; BTK - Bruton's tyrosine kinase; PLC- $\gamma 2$ - phospholipase C- $\gamma 2$; TNF-R - tumor necrosis factor receptor; TCR - T-cell receptor; TLR - Toll-like receptors; IL-1R — interleukin 1R; MAPK - mitogen-activated protein kinases; LEF — leukocyte enhancer factor; TCF - T cell-specific factor; NF $\kappa$ B - nuclear factor kappa-light-chain-enhancer of activated $B$ cells; pre-mRNA — precursor messenger RNA; mRNA - messenger RNA

reakcji polimerazy łańcuchowej (PCR, polymerase chain reaction) [51]. U około $3 \%$ chorych mutacje występują w regionie 3'UTR, co prowadzi do uszkodzenia domeny PEST w trakcie alternatywnego splicingu [52]. Niekiedy zaburzenia szlaku NOTCH1 następują w wyniku mutacji inaktywujących w genie $F B X W 7$ i są one spotykane jedynie u chorych pozbawionych mutacji w genie $N O T C H 1$ (ryc. 2) [47].

\section{Mutacje SF3B1}

Mutacje SF3B1 (splicing factor $3 b$ subunit 1) pojawiają się u 5-10\% nowo zdiagnozowanych chorych, są częstsze u osób z niezmutowanymi genami $I G H V$ i stanowią niekorzystny czynnik rokowniczy [53]. Gen SF3B1 koduje białko niezbędne w procesie wycinania sekwencji niekodujących (intronów) $z$ prekursorowego matrycowego RNA (pre-mRNA). Białko SF3B1 reguluje proces alternatywnego splicingu, w wyniku którego $z$ jednej cząsteczki pre-mRNA może powstawać kilka dojrzałych matry- cowych RNA (mRNA) dla syntezy białek (ryc. 2). Mutacje $S F 3 B 1$ w CLL są monoalleliczne, dotyczą konserwatywnej C-końcowej domeny białka i mają charakter zmiany sensu. Około 50\% przypadków mutacji $S F 3 B 1$ dotyczy zamiany aminokwasu lizyny w pozycji 700 na kwas glutaminowy (K700E) [53]. Wynikiem mutacji w $S F 3 B 1$ jest upośledzenie oddziaływania $z$ RNA [54]. W konsekwencji dochodzi do zaburzenia alternatywnego splicingu licznych genów kontrolujących cykl komórkowy, proliferację i apoptozę [54].

\section{Mutacje prowadzące do nadaktywności szlaku $\mathrm{NF} \kappa \mathrm{B}$}

Nadaktywność szlaku NF $\kappa$ B może wynikać $z$ mutacji aktywujących w pozytywnych regulatorach tej ścieżki (MYD88) lub z mutacji inaktywujących w regulatorach negatywnych $(B I R C 3, N F K B I E)$ (ryc. 2). Mutacje inaktywujące genu BIRC3 (baculoviral IAP repeat containing 3) wykrywa się 
u $4 \%$ chorych na CLL w chwili rozpoznania, jednak ich częstość zwiększa się do $24 \%$ u chorych opornych na leczenie fludarabiną, co wskazuje na to, że mutacje $\mathrm{w}$ tym genie są związane $\mathrm{z}$ rozwojem chemiooporności [35]. Białko BIRC3 reguluje negatywnie kinazę MAP3K14, która jest aktywatorem niekanonicznej ścieżki sygnałowej $\mathrm{NF} \kappa \mathrm{B}$. Mutacje BIRC3 uszkadzają C-końcową domenę RING tego białka, która jest niezbędna do przeprowadzenia proteosomalnej degradacji MAP3K14. Dlatego mutacje w BIRC3 prowadzą do konstytutywnej aktywności szlaku $\mathrm{NF} \kappa \mathrm{B}$ [47].

Mutacje aktywujące w genie MYD88 (myeloid differentiation primary response gene 88) są spotykane u 5\% chorych na CLL, głównie w M-CLL [52]. $Z$ kolei MYD88 jest białkiem adaptorowym pośredniczącym w aktywacji szlaku NF $\kappa$ B zależnej od receptorów Toll-podobnych (TLR, Toll-like receptors) [55]. Większość mutacji w MYD88 dotyczy leucyny w pozycji 265, czego konsekwencją jest zwiększone oddziaływanie produktu białkowego tego genu $z$ kinazą IRAK1, co prowadzi do nadmiernej aktywacji czynnika transkrypcyjnego STAT3 (signal transducer and activator of transcription 3) oraz białka p65 będącego podjednostką kompleksu NF $\kappa$ B [56]. W 1-3\% przypadków CLL nadaktywność szlaku $\mathrm{NF} \kappa \mathrm{B}$ wynika $z$ mutacji inaktywujących w jego negatywnym regulatorze NFKBIE (NFאB inhibitor epsilon), który ogranicza translokację $\mathrm{NF} \kappa \mathrm{B}$ do jądra komórkowego. Wynikiem mutacji jest powstanie skróconej formy białka pozbawionej funkcji regulatorowych. Mutacje w NFKBIE stanowią czynnik złego rokowania w CLL [57].

Ocena cytogenetyczna była przez wiele lat podstawą hierarchicznej klasyfikacji CLL [26]. Odkrycie istotnej wartości prognostycznej powyższych mutacji somatycznych stanowi przesłankę do uzupełnienia „klasycznego” modelu prognostycznego o zaburzenia wymienione powyżej. Badania przeprowadzone $z$ udziałem ponad 1000 nowo zdiagnozowanych chorych pozwoliły na wyróżnienie czterech grup ryzyka po integracji wyników cytogenetycznych $z$ informacją molekularną: 1) wysokiego ryzyka $z$ uszkodzonymi genami TP53 i/lub BIRC3, 2) średniego ryzyka z mutacjami w NOTCH1 i/lub SF3B1, i/lub delecją 11q, 3) niskiego ryzyka $z$ trisomią +12 lub prawidłowym kariotypem, oraz 4) bardzo niskiego ryzyka $z$ delecją 13q14 [58]. W wyniku takiej klasyfikacji około $20 \%$ chorych zaliczonych do grupy niskiego ryzyka przeklasyfikowano do grupy wysokiego ryzyka ze względu na obecność mutacji w NOTCH1, SF3B1, TP53 i BIRC3 [58]. Zarówno rezultaty tego bada- nia, jak i wyniki dwóch innych niezależnych badań potwierdzają przewagę zintegrowanej klasyfikacji cytogenetyczno-molekularnej nad dotychczasową klasyfikacją opartą wyłącznie na analizach cytogenetycznych, wskazując jednocześnie na zasadność oceny tych mutacji u chorych z CLL $[59,60]$.

\section{Zaburzenia epigenetyczne}

Zmiany epigenetyczne wpływają na ekspresję genów, oddziałując na stopień upakowania chromatyny i jej dostępność dla aparatu transkrypcyjnego bez ingerencji w sekwencję nukleotydową. Zmiany epigenetyczne polegają między innymi na modyfikacjach kowalencyjnych białek histonowych i DNA. Do regulatorów epigenetycznych zalicza się również cząstki mikro-RNA (miRNA), które modulują ekspresję genów poprzez hamowanie translacji białka oraz degradację miRNA [61]. Ponieważ modyfikacje epigenetyczne dotyczące chromatyny są katalizowane enzymatycznie, mogą być one modulowane przez inhibitory enzymów odpowiedzialnych za wprowadzanie tych zmian, zatem stanowią atrakcyjny cel terapeutyczny. Zaburzenia epigenetyczne zachodzące w CLL dotyczą głównie zaburzeń w profilu metylacji DNA. Zaobserwowano, że różnice w ekspresji miRNA między normalnymi limfocytami CD5+ a komórkami CLL wynikają $z$ aberracji genetycznych lub zaburzonej metylacji regionów DNA, w tym tych odpowiedzialnych za ekspresję miRNA [62].

Metylacja DNA polega na odwracalnym dodaniu do nukleotydu cytozynowego reszty metylowej, co w konsekwencji czyni taki fragment DNA nieaktywnym transkrypcyjnie [63]. Regulacja metylacji DNA odgrywa istotną rolę podczas dojrzewania limfocytu B. Począwszy od stadium naiwnego limfocytu B, a na komórce pamięci kończąc, DNA limfocytu ulega stopniowej demetylacji obejmującej głównie regiony DNA odpowiedzialne za wspomaganie transkrypcji (tzw. enhancery) oraz regiony wiązania czynników transkrypcyjnych $[12,13]$. Najbardziej drastyczne zmiany w profilu metylacji DNA (metylomie) komórki B zachodzą podczas reakcji germinalnej [12]. W stosunku do prawidłowych limfocytów CD5+ populacja komórek CLL charakteryzuje się wyższym stopniem globalnej demetylacji DNA, który dotyczy między innymi genów związanych ze szlakiem BCR, kostymulacją limfocytów T oraz interakcją cytokin [12]. Globalnej demetylacji w CLL towarzyszy lokalna hipermetylacja, która obejmuje głównie geny supresorów nowotworów [64]. Mimo że zaburzenia metylacji DNA w komórce CLL mają charakter 
globalny, to jedynie w odniesieniu do 5-10\% genów stwierdza się istnienie korelacji między stopniem metylacji a ekspresją genu [12]. Dlatego sugeruje się, że zmiany metylacji DNA mogą mieć charakter funkcjonalny tylko na pewnym etapie dojrzewania limfocytu B [12].

Komórki CLL różnią się wzorem metylacji zależnie od stanu mutacji IGHV. Komórki z niezmutowanymi genami $I G H V$ charakteryzują się wzorem metylacji zbliżonym do naiwnego limfocytu B, natomiast komórki $z$ mutacjami somatycznymi w IGHV pod względem metylomu przypominają komórki pamięci $[12,13]$. Wzór metylacji DNA ma znaczenie rokownicze. Rokowanie u chorych na CLL z metylomem zbliżonym do naiwnej komórki B, czyli niskim stopniem programowania epigenetycznego, jest znacznie gorsze niż u chorych $z$ metylomem zbliżonym do komórki pamięci (wysokim stopniem programowania epigenetycznego) [13]. Wyróżnia się również trzeci podtyp epigenetyczny, który charakteryzuje się pośrednim metylomem i niższą częstością mutacji somatycznych w $I G H V$ w stosunku do komórek M-CLL. Podtyp ten cechuje pośrednie rokowanie, a jego prawidłowym odpowiednikiem jest prawdopodobnie komórka B, która po kontakcie $z$ antygenem przebyła różnicowanie pozagerminalne [12, 65].

Zaburzenia epigenetyczne są częstym $z$ darzeniem w CLL występującym równolegle ze zmianami genetycznymi. Zdefiniowanie epigenetycznych podtypów CLL może w przyszłości pomóc w dokładniejszym prognozowaniu oraz klasyfikacji chorych do leczenia.

\section{Ewolucja klonalna}

Pierwsze zaburzenia genetyczne i epigenetyczne predysponujące do rozwoju CLL mogą występować długo przed rozwojem choroby. U około $10 \%$ populacji powyżej 60 . roku życia pewne zmiany genetyczne są następstwem klonalnej hematopoezy, która zwiększa ryzyko zachorowania na nowotwory hematologiczne, w tym CLL [66]. Rozwój CLL przeważnie jest poprzedzony wystąpieniem MBL, która się pojawia do 6 lat przed rozpoznaniem CLL [67]. Poza podwyższoną liczbą komórek B, nieprzekraczającą jednak 5000 komórek/ $\mu$ l krwi obwodowej, osoby $z$ MBL nie wykazują innych objawów chorobowych [5]. Rocznie 1-3\% przypadków z MBL transformuje do CLL [5, 68]. Choć komórki CLL cechuje nagromadzenie większej ilości uszkodzeń niż komórki w stadium MBL, to niektóre z zaburzeń genetycznych typowych dla CLL (np. del13q14, trisomia +12 , mutacje NOTCH1, ATM, FBXW7) występują już na etapie MBL [52, 69]. Podczas przebiegu CLL częstość niektórych mutacji pozostaje zbliżona, tak jak w przypadku mutacji MYD88 [70]. Jednak w przypadku większości genów częstość mutacji zmienia się wraz z progresją choroby [70]. U chorych $z$ nawrotem CLL częstość mutacji NOTCH1 jest 2-krotnie większa (ok. 25\%) niż u chorych przed zastosowaniem pierwszej linii leczenia $(<10 \%)$ [70]. Podobnie mutacje SF3B1 są wykrywane u nowo zdiagnozowanych chorych $\mathrm{z}$ częstością 4-9\%, ale częstość ta wzrasta do 17-18\% u chorych wymagających rozpoczęcia leczenia [70]. Mutacje TP53, NOTCH1, SF3B1 i BIRC3 występują $z$ małą częstością (ok. 5\%) u chorych w momencie rozpoznania i mają charakter subklonalny. Częstość tych mutacji zwiększa się do 20-25\% $\mathrm{u}$ chorych nieodpowiadających na fludarabinę, co wskazuje na udział wymienionych mutacji w rozwoju oporności na ten chemioterapeutyk [71]. Z kolei przypadki CLL, które uległy transformacji do agresywnego chłoniaka (zespół Richtera), cechują się wysoką częstością mutacji TP53 (60\%), NOTCH1 (40\%) MYC (ok. 30\%) i CDKN2A/CDKN2B (ok. $30 \%$ ) w porównaniu $z$ chorymi bez richteryzacji [72]. Badania te wskazują, że w trakcie trwania choroby w obrębie populacji komórek nowotworowych dochodzi do selekcji komórek (subklonów) lepiej przystosowanych biologicznie do zmieniających się warunków. Ten darwinowski model selekcji klonalnej szczególnie przyspiesza chemioterapia, która wprowadza silną presję selekcyjną eliminującą wrażliwe populacje komórek, natomiast komórki dysponujące zmianami sprzyjającymi chemiooporności zyskują przewagę biologiczną, a co za tym następuje - stopniową przewagę liczebną $[28,70,73,74]$.

Subklonalny charakter niektórych mutacji stanowi duże utrudnienie w diagnostyce i ogranicza ich wykorzystanie jako markerów prognostycznych. Sekwencjonowanie metodą Sangera nie umożliwia wykrycia małych populacji subklonów z niekorzystną mutacją ze względu na ograniczoną czułość. Wykrywanie takich subklonów jest możliwe znacznie bardziej czułą metodą sekwencjonowania nowej generacji. Badania techniką NGS wskazują, że obecność mutacji TP53, nawet o bardzo niskiej częstości ( $<3$ komórki/1000), prowadzi w przyszłości do ekspansji klonu komórek $z$ tą mutacją [75], dlatego możliwość wykrywania subklonów niekorzystnie obciążonych genetycznie już na wczesnych etapach mogłaby zapobiec ich ekspansji w późniejszych fazach choroby. 
Komórki CLL charakteryzują się nie tylko heterogennością genetyczną, ale również epigenetyczną. Komórki białaczkowe pobrane od tego samego chorego cechuje większa różnorodność profilu metylacji (metylomu) niż limfocyty pobrane od zdrowego dawcy [76]. Heterogenność epigenetyczna dotyczy zwykle konkretnych alleli (np. sekwencji regulatorowych genów związanych z macierzystością) i koreluje ze zmiennością transkryptomu [77]. Wysoki stopień różnorodności metylomu komórek CLL u chorego jest związany $z$ bardziej agresywnym przebiegiem choroby i niekorzystnym rokowaniem $[76,77]$.

Powyższe przykłady pokazują, że CLL jest chorobą genetycznie i epigenetycznie heterogenną, a zmienność ta jest motorem napędzającym klonalną ewolucję. Przewlekła białaczka limfocytowa charakteryzuje się współwystępowaniem wielu klonów nowotworowych komórek, które rywalizują między sobą i podlegają nieustannej ewolucji podczas rozwoju choroby. Klonalna ewolucja jest procesem dynamicznym, w którym komórki nagromadzają genetyczne oraz epigenetyczne zmiany dające początek nowym klonom podlegającym ekspansji, różnicowaniu i selekcji. Heterogenność genetyczna i epigenetyczna sprzyjają klonalnej ewolucji, ponieważ zwiększają szanse wyłonienia najbardziej dostosowanego klonu komórek, dlatego są one markerem złego rokowania [70].

\section{Mikrośrodowisko}

Interakcje $z$ mikrośrodowiskiem odgrywają istotną rolę $\mathrm{w}$ patogenezie CLL, a ich przerwanie skutkuje spontaniczną apoptozą komórek białaczkowych, którą można powstrzymać, dodając do hodowli komórki opiekuńcze (NLC, nurse-like cells) lub komórki podścieliska (BMSC, bone marrow stromal cells) [78, 79]. Komórki CLL rezydujące $\mathrm{w}$ węzłach chłonnych charakteryzują się wyższą aktywnością szlaków BCR i $\mathrm{NF}_{\kappa} \mathrm{B}$ niż komórki CLL wyizolowane $z$ krwi obwodowej i szpiku kostnego [17]. Komórki CLL cyrkulują między krwią obwodową a narządami limfoidalnymi, w których znajdują się ośrodki namnażania komórek białaczkowych [7]. Cyrkulacja komórek białaczkowych między narządami limfoidalnymi i krwią obwodową jest regulowana za pomocą chemokin wydzielanych przez komórki mikrośrodowiska oraz na drodze bezpośrednich kontaktów między cząsteczkami adhezyjnymi na powierzchni komórek CLL a odpowiadającymi im ligandami na powierzchni komórek mikrośrodowiska. Oba sposoby komunikacji mają charakter dwukierunkowy. Do istotnych kompo- nentów mikrośrodowiska w CLL należą BMSC, NLC różnicujące się z monocytów, grudkowe komórki dendytyczne (FDC, follicular dendritic cells), komórki śródbłonka oraz limfocyty T [24].

Komórki opiekuńcze powstają z monocytów na drodze spontanicznego różnicowania, w którym istotną rolę odgrywa białko HMGB1 (high-mobility group protein B-1) uwalniane do osocza przez komórki CLL [80]. Komórki NLC indukują migrację komórek CLL do węzłów chłonnych poprzez sekrecję ligandów CXCL12 i CXCL13 (C-X-C motif chemokine ligand 12/13) oraz ekspresję cząsteczek BAFF (B-cell activating factor) i APRIL (proliferation-inducing ligand) (ryc. 3). Interakcje $z$ NLC prowadzą do wzrostu aktywności szlaków przeżyciowych $\mathrm{BCR}$ i $\mathrm{NF}_{\kappa} \mathrm{B}$ w komórkach CLL [17]. Aktywacja BCR odbywa się również poprzez jego interakcję $z$ antygenami, wimentyną i kalretikuliną, na powierzchni NLC, zaś aktywacja $\mathrm{NF} \kappa \mathrm{B}$ następuje poprzez wydzielanie przez $\mathrm{NLC}$ do osocza cząsteczek CD14 (ryc. 3) [81, 82].

Komunikacja komórek CLL $z$ komórkami podścieliska odbywa się poprzez interakcje pleksyna B1-CD100 oraz wiązanie cząsteczek adhezji komórkowej naczyń 1 (VCAM1, vascular cell adhesion molecule 1) do integryny CD49d i prowadzi do wzrostu ekspresji ZAP70 i CD38 w komórkach CLL (ryc. 3) [83]; CD38 jest przezbłonowym białkiem wspierającym interakcję komórek CLL $z$ limfocytami T i komórkami NLC, zaś kinaza ZAP70 potęguje sygnał od BCR [84, 85]. Zarówno wysoka ekspresja CD38, jak i wysoka ekspresja ZAP70 są czynnikami złego rokowania $\mathrm{w}$ CLL $[86,87]$. Ponadto interakcje $z$ BMSC powodują obniżenie ekspresji CD20 na powierzchni komórek CLL, co w konsekwencji zmniejsza ich wrażliwość na działanie przeciwciał anty-CD20, takich jak rytuksymab [88]. Komórki CLL aktywują BMSC, między innymi poprzez uwalnianie mikropęcherzyków zawierających aktywne białka sygnałowe [89].

Komórki CLL wiążą się $z$ integrynami $\beta_{1}$ i $\beta_{2}$ oraz cząsteczkami BAFF i APRIL na powierzchni komórek śródbłonka [90]. Istotnym oddziaływaniem promującym przeżywalność i rozwój chemiooporności komórek CLL z udziałem szlaków MAPK i PI3K jest wiązanie peptydu endoteliny 1 (ET1) na powierzchni komórek CLL przez receptor ETAR (endothelin subtype A receptor) (ryc. 3) [91]. $Z$ kolei FDC chronią komórki CLL przed spontaniczną apoptozą poprzez sygnały od ligandu CD44, kompleksu CD100-pleksyna B1 oraz kompleksu limfotoksyna $\alpha / \beta$-receptor LT $\beta$ (ryc. 3). Sygnały te prowadzą do nadekspresji anty-apoptotycznego białka MCL1 (myeloid cell leukemia 1) w komórkach CLL, co promuje ich przeżywalność [91, 92]. 


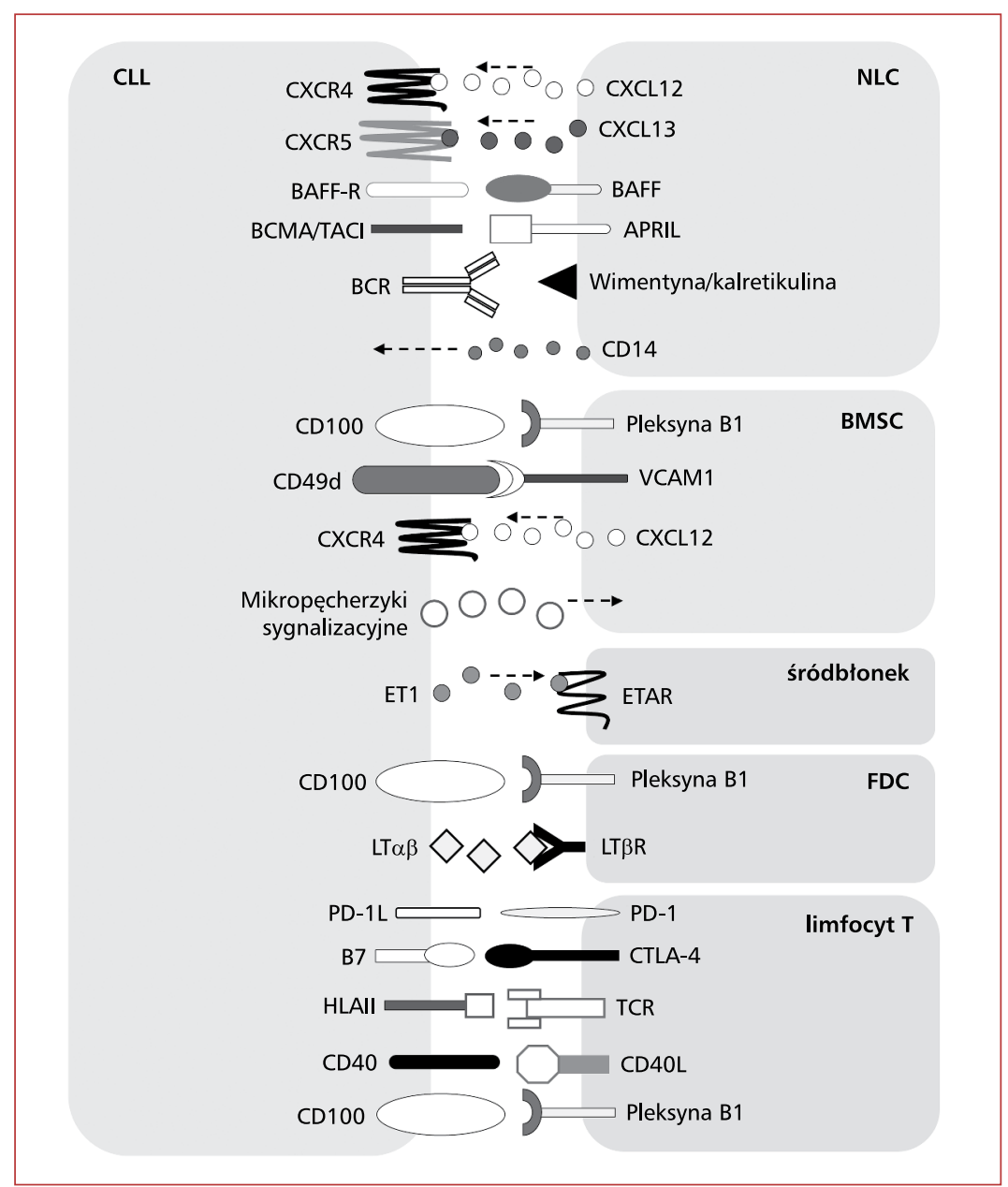

Rycina 3. Wybrane interakcje komórek przewlekłej białaczki limfocytowej (CLL) z mikrośrodowiskiem; NLC — komórki opiekuńcze; BAFF — czynnik aktywujący komórki B; APRIL — ligand indukujący proliferację; BCR — receptor B-komórkowy; BMSC — komórki podścieliska; VCAM1 - cząsteczka adhezji komórkowej naczyń 1; ET1 - endotelina 1; ETAR — receptor endoteliny typu A; FDC — grudkowe komórki dendrytyczne; LT $\alpha \beta$ — limfotoksyna $\alpha \beta$; LTßR — receptor limfotoksyny $\beta$; PD-1L - ligand programowanej śmierci komórki 1; PD-1 - białko programowanej śmierci komórki 1; CTLA-4 - cytotoksyczne limfocyty T związane z białkiem 4; TCR — receptor T-komórkowy

Figure 3. Selected interactions of chronic lymphocytic leukemia (CLL) cells with their microenvironment; NLC nurse-like cells; BAFF — B-cell activating factor; APRIL — proliferation-inducing ligand; BCR - B-cell receptor; BMSC — bone marrow stromal cells; VCAM1 - vascular cell adhesion molecule 1; ET1 — endothelin 1; ETAR - endothelin subtype A receptor; FDC - follicular dendritic cells; LT $\alpha \beta-\operatorname{limphotoxin} \alpha \beta$; LTßR - limphotoxin $\beta$ receptor; PD-1L — programmed cell death 1 ligand; PD-1 — programmed cell death protein 1; CTLA-4 - cytotoxic T-lymphocyte-associated protein 4; TCR - T-cell receptor

Limfocyty T i komórki naturalnej cytotoksyczności (NK, natural killers) chorych na CLL cechuje upośledzenie funkcji efektorowych, co może częściowo tłumaczyć zdolność komórek białaczkowych do uniknięcia destrukcji ze strony układu immunologicznego. Mimo zwiększonej liczby efektorowych limfocytów pamięci CD4+ i krańcowo zróżnicowanych limfocytów CD8 + u chorych w zaawansowanym stadium CLL komórki te cechują upośledzona zdolność do formowania synaps immunologicznych oraz zmniejszona ruchliwość [93-95]. Limfocyty T od chorych na CLL charakteryzują się zwiększoną ekspresją białka programowanej śmierci komórki 1 (PD-1, programmed cell death protein 1) oraz białka CTLA-4 (cytotoxic T-lymphocyte-associated protein 4), których pobudzenie powoduje zjawisko wyczerpania limfocytów T i hamowanie odpowiedzi immunologicznej [93, 96, 97]. 
Chemokiny i cząsteczki adhezyjne

Migracja komórek białaczkowych do ośrodków namnażania odbywa się pod ścisłą kontrolą chemokin. Istotną rolę $\mathrm{w}$ tym procesie odgrywają chemokiny CXCL12 (wcześniej znane jako SDF1 [stromal cells-derived factor 1]) oraz CXCL13. Chemokina CXCL13 jest produkowana przez NLC i rozpoznawana przez receptor CXCR5 na powierzchni komórek CLL [98]. Z kolei chemokina CXCL12 jest produkowana zarówno przez NLC jak i BMSC. Chemokina CXCL12 wiąże się do receptora CXCR4, powodując aktywację przeżyciowej kinazy ERK (extracellular signal-regulated kinase), czynnika transkrypcyjnego STAT3 (signal transducer and activator of transcription 3) i szlaku kinazy mTOR (mammalian target of rapamycin) [99-101]. Poziom ekspresji CXCR4 na powierzchni komórek CLL jest 4-krotnie wyższy niż na powierzchni prawidłowych limfocytów B [102]. Wysoki poziom powierzchniowej ekspresji CXCR4 w komórkach CLL wiąże się z wyższym ryzykiem infiltracji komórek CLL do narządów limfoidalnych i w konsekwencji jest czynnikiem złego rokowania [103]. Powierzchniową ekspresję CXCR4 zwiększa fosforylacja przez serynowo-treoninową kinazę PIM1 (proviral integration site for moloney murine leukemia virus), która ulega nadekspresji w komórkach CLL [103]. Wiązanie CXCL12 do CXCR4 powoduje endocytozę kompleksu receptor-ligand, co prowadzi do obniżonej powierzchniowej ekspresji CXCR4. W konsekwencji ekspresja CXCR4 na powierzchni komórek CLL jest wysoka we krwi obwodowej i niska w ośrodkach namnażania, gdzie stężenie CXCL12 pozostaje wysokie [104].

Mikrośrodowisko jako cel terapeutyczny w CLL

Ze względu na istotną rolę w patogenezie mikrośrodowisko komórek CLL jawi się jako atrakcyjny cel terapeutyczny. Wśród potencjalnych leków celujących w interakcje między komórkami białaczkowymi a ich środowiskiem należy wymienić związki immunomodulujące, inhibitory szlaku BCR oraz ścieżki sygnałowej od CXCR4/CXCL12. Przykładem związku immunomodulującego o plejotropowym wpływie na mikrośrodowisko jest lenalidomid. Efekt działania tego leku obejmuje zahamowanie proliferacji komórek CLL na drodze mechanizmu zależnego od białek cereblon i p21, interferencje $z$ sygnałami pochodzącymi od NLC i komórek śródbłonkowych oraz zwiększenie antynowotworowej odpowiedzi immunologicznej ze strony limfocytów T i komórek NK [105-108].
Aktywacja BCR wywiera plejotropowy wpływ na komórki CLL, który obejmuje wzrost ekspresji integryn i adhezji komórkowej oraz sekrecję chemokin CCL3 i CCL4. W konsekwencji zahamowanie szlaku BCR prowadzi również do zaburzeń interakcji komórek CLL $z$ ich mikrośrodowiskiem. Zgodnie $z$ tym mechanizmem inhibitory BTK (np. ibrutynib) upośledzają migrację i adhezję komórek CLL oraz hamują wydzielanie CCL3 i CCL4 [109, 110].

Jak wyżej wskazano, kluczową rolę w regulacji migracji komórek CLL pełni oś CXCR4-CXCL12. Działanie tego układu sygnałowego można wyłączyć za pośrednictwem bezpośrednich antagonistów CXCR4 (AMD3100/pleriksafor, BTK140), przeciwciał anty-CXCR4 (MDX1338/BMS93656) lub oligonukleotydów RNA neutralizujących CXCL12 (NOX-A12) [24, 111]. Pleriksafor hamuje chemotaksję komórek CLL i upośledza ich interakcje $z$ NLC i BMSC, prowadząc do uwolnienia komórek CLL $z$ węzłów chłonnych do krwi obwodowej [112]. Podobne działanie wykazuje NOX-A12 [113].

Powierzchniowa ekspresja CXCR4 jest regulowana na drodze fosforylacji przez kinazę PIM1, dlatego w ostatnich latach rozważa się zastosowanie inhibitorów kinaz PIM jako potencjalnej strategii terapeutycznej w CLL. Inhibicja tych kinaz upośledza migrację komórek CLL w gradiencie CXCL12 poprzez zmniejszenie powierzchniowej ekspresji CXCR4 oraz hamowanie aktywności kinazy mTOR niezbędnej do migracji komórek białaczkowych [46, 103]. Ponieważ kinazy PIM ulegają nadekspresji pod wpływem sygnałów dostarczanych przez mikrośrodowisko, to zahamowanie ich aktywności przełamuje przeżyciowe sygnały dostarczane z zewnątrz i w konsekwencji prowadzi do śmierci komórek CLL [46].

\section{Podsumowanie}

Badania $z$ ostatnich 10 lat $z$ wykorzystaniem nowoczesnych technik biologii molekularnej znacząco wzbogaciły dotychczasową wiedzę na temat molekularnej patogenezy CLL. Poczyniono postępy w ustaleniu pochodzenia tej choroby oraz głębiej poznano jej genetyczną i epigenetyczną architekturę. W świetle tych badań CLL jest chorobą genetycznie i epigenetycznie heterogenną, co $z$ jednej strony tłumaczy zróżnicowane spektrum klinicznych prezentacji i przebiegu choroby, ale $z$ drugiej znacząco komplikuje zakres i metodykę badań niezbędnych do nowoczesnej diagnostyki tego schorzenia. Diagnostyka molekularna nowoczesnymi i czułymi metodami NGS pozwala nie 
tylko na kompleksową identyfikację mutacji o znaczeniu patogenetyczno-prognostycznym, ale także na wykrycie ich subklonalnego ładunku. Poznanie i zrozumienie występujących u danego chorego mutacji i ich architektury klonalnej może stanowić racjonalną podstawę indywidualizacji terapii tej choroby w przyszłości. Wyzwaniem najbliższych lat będzie zatem kliniczne wykorzystanie uzyskanej wiedzy molekularnej.

\section{Piśmiennictwo}

1. Dores G.M., Anderson W.F., Curtis R.E. i wsp. Chronic lymphocytic leukaemia and small lymphocytic lymphoma: overview of the descriptive epidemiology. Br. J. Haematol. 2007; 139: 809-819.

2. Richardson D.B., Wing S., Schroeder J. i wsp. Ionizing radiation and chronic lymphocytic leukemia. Environ. Health Perspect. 2005; 113: 1-5.

3. Goldin L.R., Pfeiffer R.M., Li X. i wsp. Familial risk of lymphoproliferative tumors in families of patients with chronic lymphocytic leukemia: results from the Swedish Family-Cancer Database. Blood 2004; 104: 1850-1854.

4. Strati P., Shanafelt T.D. Monoclonal B-cell lymphocytosis and early-stage chronic lymphocytic leukemia: diagnosis, natural history, and risk stratification. Blood 2015; 126: 454-462.

5. Hallek M. Chronic lymphocytic leukemia: 2015 update on diagnosis, risk stratification, and treatment. Am. J. Hematol. 2015; 90: 446-460.

6. Ponzoni M., Doglioni C., Caligaris-Cappio F. i wsp. Chronic lymphocytic leukemia: the pathologist's view of lymph node microenvironment. Semin. Diagn. Pathol. 2011; 28: 161-166.

7. Messmer B.T., Messmer D., Allen S.L. i wsp. In vivo measurements document the dynamic cellular kinetics of chronic lymphocytic leukemia B cells. J. Clin. Invest. 2005; 115: 755-764.

8. Parikh S.A., Shanafelt T.D. Prognostic markers and risk stratification in chronic lymphocytic leukemia. Semin. Oncol. 2016; 43: 233-240.

9. Zenz T., Mertens D., Kuppers R. i wsp. From pathogenesis to treatment of chronic lymphocytic leukemia. Nat. Rev. Cancer 2010; 10: 37-50.

10. Matutes E., Owusu-Ankomah K., Morilla R. i wsp. The immunological profile of B-cell disorders and proposal of a scoring system for the diagnosis of CLL. Leukemia 1994; 8: 1640-1645.

11. Seiffert M., Schulz A., Ohl S. i wsp. Soluble CD14 is a novel monocyte-derived survival factor for chronic lymphocytic leukemia cells, which is induced by CLL cells in vitro and present at abnormally high levels in vivo. Blood 2010; 116: 4223-4230.

12. Kulis M., Heath S., Bibikova M. i wsp. Epigenomic analysis detects widespread gene-body DNA hypomethylation in chronic lymphocytic leukemia. Nat. Genet. 2012; 44: 1236-1242.

13. Oakes C.C., Seifert M., Assenov Y. i wsp. DNA methylation dynamics during $\mathrm{B}$ cell maturation underlie a continuum of disease phenotypes in chronic lymphocytic leukemia. Nat. Genet. 2016; 48: 253-264.

14. Kikushige Y., Ishikawa F., Miyamoto T. i wsp. Self-renewing hematopoietic stem cell is the primary target in pathogenesis of human chronic lymphocytic leukemia. Cancer Cell 2010; 16: 246-259.

15. Damm F., Mylonas E., Cossan A. i wsp. Acquired initiating mutations in early hematopoietic cells of CLL patients. Cancer Discov. 2014; 4: 1088-1101.

16. Seda V., Mraz M. B-cell receptor signaling and its crosstalk with other pathways in normal and malignant cells. Eur. J. Haematol. 2015; 94: 193-205.
17. Herishanu Y., Perez-Galan P., Liu D. i wsp. The lymph node microenvironment promotes B-cell receptor signaling, NF-kappaB activation, and tumor proliferation in chronic lymphocytic leukemia. Blood 2011; 13: 563-574.

18. Burger J.A., Chiorazzi N. B-cell receptor signaling in chronic lymphocytic leukemia. Trends Immunol. 2013; 34: 592-601.

19. Vardi A., Agathangelidis A., Sutton L.A. i wsp. Immunogenetic studies of chronic lymphocytic leukemia: revelations and speculations about ontogeny and clinical evolution. Cancer Res. 2014; 74: 4211-4216.

20. Chu C.C., Catera R., Hatzi K i wsp. Chronic lymphocytic leukemia antibodies with a common stereotypic rearrangement recognize nonmuscle myosin heavy chain IIA. Blood 2008; 112: 5122-5129.

21. Lanemo Myhrinder A., Hellqvist E., Sidorova E. i wsp. A new perspective: molecular motifs on oxidized LDL, apoptotic cells, and bacteria are targets for chronic lymphocytic leukemia antibodies. Blood 2008; 111: 3838-3848.

22. Kostareli E., Gounari M., Janus A. i wsp. Antigen receptor stereotypy across B-cell lymphoproliferations: the case of IGHV4-59/ /IGKV3-20 receptors with rheumatoid factor activity. Leukemia 2012; 26: 1127-1131.

23. Duhren-von Minden M., Ubelhart R., Schneider D. i wsp. Chronic lymphocytic leukemia is driven by antigen-independent cell-autonomous signaling. 2012; 489: 309-312.

24. Ten Hacken E., Burger J.A. Microenvironment interactions and B-cell receptor signaling in chronic lymphocytic leukemia: implications for disease pathogenesis and treatment. 2016; 1863: 401-413.

25. Vogelstein B., Papadopoulos N., Velculescu V.E. i wsp. Cencer genome landscapes. Science 2013; 339: 1546-1558.

26. Dohner H., Stilgenbauer S., Benner A. i wsp. Genomic aberrations and survival in chronic lymphocytic leukemia. N. Engl. J. Med. 2000; 343: 1910-1906.

27. Haferlach C., Dicker F., Schnittger S. i wsp. Comprehensive genetic characterization of CLL: a study on 506 cases analysed with chromosome banding analysis, interphase FISH, $\operatorname{IgV}(\mathrm{H})$ status and immunophenotyping. Leukemia 2007; 21: 2442-2451.

28. Landau D.A., Tausch E., Taylor-Weiner A.N. i wsp. Mutations driving CLL and their evolution in progression and relapse. Nature 2015; 526: 525-530.

29. Calin G.A., Dumitru C.D., Shimizu M. i wsp. Frequent deletions and down-regulation of micro-RNA genes miR15 and miR16 at 13q14 in chronic lymphocytic leukemia. Proc. Natl. Acad. Sci. USA 2002; 99: 15524-15529.

30. Palamarchuk A., Efanov A., Nazaryan N. i wsp. 13q14 deletions in CLL involve cooperating tumor suppressors. Blood 2010; 115: 3916-3922.

31. Ouillette P., Collins R., Shakhan S. i wsp. The prognostic significance of various 13q14 deletions in chronic lymphocytic leukemia. Clin. Cancer Res. 2011; 17: 6778-6790.

32. Shiloh Y., Ziv Y. The ATM protein kinase: regulating the cellular response to genotoxic stress, and more. Nat. Rev. Mol. Cell Biol. 2013; 14: 197-210.

33. Skowronska A., Parker A., Ahmed G. i wsp. Biallelic ATM inactivation significantly reduces survival in patients treated on the United Kingdom Leukemia Research Fund Chronic Lymphocytic Leukemia 4 trial. J. Clin. Oncol. 2012; 30: 4524-4532.

34. Stankovic T., Skowronska A. The role of ATM mutations and 11q deletions in disease progression in chronic lymphocytic leukemia. Leuk. Lymphoma 2014; 55: 1227-1239.

35. Rossi D., Fangazio M., Rasi S. i wsp. Disruption of BIRC3 associates with fludarabine chemorefractoriness in TP53 wild-type chronic lymphocytic leukemia. Blood 2012; 119: 2854-2862.

36. Gorniak P., Budziszewska B., Pula B. i wsp. Increased expression of $\mathrm{E} 3$ ubiquitin ligases targeting p53 CLL patients with wild-type TP53 exhibits associations with clinical features of the disease. Leuk. Lymphoma 2016; 57: 1471-1473. 
37. Strati P., Abruzzo L.V., Wierda W.G. i wsp. Second cancers and Richter transformation are the leading causes of death in patients with trisomy 12 chronic lymphocytic leukemia. Clin. Lymphoma Myeloma Leuk. 2015; 15: 420-427.

38. Chigrinova E., Rinaldi A., Kwee I. i wsp. Two main genetic pathways lead to the transformation of chronic lymphocytic leukemia to Richter syndrome. Blood 2013; 122: 2673-2682.

39. Bieging K.T., Mello S.S., Attardi L.D. Unraveling mechanisms of p53-mediated tumour suppression. Nat. Rev. Cancer 2014; 14: 359-370.

40. Yu L., Kim H., Kasar S.N. i wsp. Survival of del17p CLL depends on genomic complexity and somatic mutation. Clin. Cancer Res. 2017; 23: 735-745.

41. Malcikova J., Smardova J., Rocnova L. i wsp. Monoallelic and biallelic inactivation of TP53 gene in chronic lymphocytic leukemia: selection, impact on survival, and response to DNA damage. Blood 2009; 114: 5307-5314.

42. Pospisilova S., Gonzalez D., Malcikova J. i wsp. ERIC recommendations on TP53 mutation analysis in chronić lymphocytic leukemia. Leukemia 2012; 26: 1458-1461.

43. Lee H.J., Gallardo M., Ma H. i wsp. p53-independent ibrutinib responses in an E $\mu$-TCL1 mouse model demonstrates efficacy in high-risk CLL. 2016; 6: e434.

44. Furman R.R., Sharman J.P., Coutre S.E. i wsp. Idelalisib and rituximab in relapsed chronic lymphocytic leukemia. N. Engl. J. Med. 2014; 370: 997-1007.

45. Anderson M.A., Deng J., Seymour J.F. i wsp. The BCL2 selective inhibitor venetoclax induces rapid onset apoptosis of CLL in patients via a TP53-independent mechanism. Blood 2016; 127: 3215-3224.

46. Bialopiotrowicz E., Gorniak P., Pula B. i wsp. Microenvironment-induced expression of PIM kinases supports chronic lymphocytic leukemia cells survival and promotes CXCR4-mTOR pathway dependent migration. Blood 2016; 128: 3239.

47. Fabbri G., Dalla-Favera R. The molecular pathogenesis of chronic lymphocytic leukemia. Nat. Rev. Cancer 2016; 16: 145-162.

48. Wang L., Lawrence M.S., Wan Y. i wsp. SF3B1 and other novel cancer genes in chronic lymphocytic leukemia. N. Engl. J. Med. 2011; 365: 2497-2506.

49. Ramsay A.J., Rodriguez D., Villamor N. i wsp. Frequent somatic mutations in components of the RNA processing machinery in chronic lymphocytic leukemia. Leukemia 2013; 27: 1600-1603.

50. Del Giudice I., Rossi D., Chiaretti S. i wsp. NOTCH1 mutations in +12 chronic lymphocytic leukemia (CLL) confer an unfavourable prognosis, induce a distinctive transcriptional profiling and refine the intermediate prognosis of +12 CLL. Haematologica 2012; 97: 437-441.

51. Bilous N.I., Abramenko I.V., Chumak A.A. i wsp. Detection of NOTCH1 c.7541_7542delCT mutation in chronic lymphocytic leukemia using conventional and real-time polymerase chain reaction. Exp. Oncol. 2016; 38: 112-116.

52. Puente X.S., Bea S., Valdes-Mas R. i wsp. Non-coding recurrent mutations in chronic lymphocytic leukaemia. Nature 2015; 526: 519-524.

53. Quesada V., Conde L., Villamor N. i wsp. Exome sequencing identifies recurrent mutations of the splicing factor SF3B1 gene in chroni lymphocytic leukemia. Nat. Genet. 2011; 44: 47-52.

54. Golas M.M., Sander B., Will C.L. i wsp. Molecular architecture of the multiprotein splicing factor SF3b. Science 2003; 300: 980-984.

55. Rawlings D.J., Schwartz M.A., Jackson S.W. i wsp. Integration of B cell responses through Toll-like receptors and antigen receptors. Nat. Rev. Immunol. 2012; 12: 282-294.

56. Puente X.S., Pinyol M., Quesada V. i wsp. Whole-genome sequencing identifies recurrent mutations in chronic lymphocytic leukemia. Nature 2011; 475: 101-105.

57. Mansouri L., Sutton L.A., Ljungstrom V. i wsp. Functional loss of $\mathrm{I} \kappa \mathrm{B} \varepsilon$ leads to NF- $\kappa \mathrm{B}$ deregulation in aggressive chronic lymphocytic leukemia. J. Exp. Med. 2015; 212: 833-843.
58. Rossi D., Rasi S., Spina V. i wsp. Integrated mutational and cytogenetic analysis identifies new prognostic subgroups in chronic lymphocytic leukemia. Blood 2013; 121: 1403-1412.

59. Jeronim S., Weissmann S., Haferlach C. i wsp. SF3B1 mutations correlated to cytogenetics and mutations in NOTCH1, FBXW7, MYD88, XPO1 and TP53 in 1160 untreated CLL patients. Leukemia 2014; 28: 108-117.

60. Baliakas P., Hadzidimitriou A., Sutton L.A. i wsp. Recurrent mutations refine prognosis in chronic lymphocytic leukemia. Leukemia 2015; 29: 329-336.

61. Bartel D.P. MicroRNAs: genomics, biogenesis, mechanism, and function. Cell 2004; 116: 281-297.

62. Baer C., Claus R., Frenzel L.P. i wsp. Extensive promoter DNA hypermethylation and hypomethylation is associated with aberrant microRNA expression in chronic lymphocytic leukemia. Cancer Res. 2012; 72: 3775-3785.

63. Wu H., Zhang Y. Reversing DNA methylation: mechanisms, genomics, and biological functions. Cell 2014; 156: 45-68.

64. Kanduri M., Cahil N., Goransson H. i wsp. Differential genome-wide array-based methylation profiles in prognostic subsets of chronic lymphocytic leukemia. Blood 2010; 115: 296-305.

65. Chiorazzi N., Ferrarini M. Cellular origin(s) of chronic lymphocytic leukemia: cautionary notes and additional considerations and possibilities. Blood 2011; 117: 1781-1791.

66. Genovese G., Kahler A.K., Handsaker R.E. i wsp. Clonal hematopoiesis and blood-cancer risk inferred from blood DNA sequence. N. Engl. J. Med. 2014; 371: 2477-2487.

67. Landgren O., Albitar M., Ma W. i wsp. B-cell clones as early markers for chronic lymphocytic leukemia. N. Engl. J. Med. 2009; 360: 659-667.

68. Rawstron A.C., Bennett F.L., O’Connor S.J. i wsp. Monoclonal B-cell lymphocytosis and chronic lymphocytic leukemia. N. Engl. J. Med. 2008; 359: 575-583.

69. Ojha J., Secreto C., Rabe K. i wsp. Monoclonal B-cell lymphocytosis is characterized by mutations in CLL putative driver genes and clonal heterogeneity many years before disease progression. Leukemia 2014; 28: 2395-2398.

70. Guieze R., Wu C.J. Genomic and epigenomic heterogeneity in chronic lymphocytic leukemia. Blood 2015; 126: 445-453.

71. Messina M., Del Giudice I., Khiabanian H. i wsp. Genetic lesions associated with chronic lymphocytic leukemia chemo-refractoriness. Blood 2014; 123: 2378-2388.

72. Fabbri G., Khiabanian H., Holmes A.B. i wsp. Genetic lesions associated with chronic lymphocytic leukemia transformation. J. Exp. Med. 2013; 210: 2273-2288.

73. Landau D.A., Carter S.L., Stojanov P. i wsp. Evolution and impact of subclonal mutations in chronic lymphocytic leukemia. Cell 2013; 152: 714-726.

74. Wang J., Khiabanian H., Rossi D. i wsp. Tumor evolutionary directed graphs and the history of chronic lymphocytic leukemia. Elife 2014; 3:e02869.

75. Rossi D., Khiabanian H., Spina V. i wsp. Clinical impact of small TP53 mutated subclones in chronic lymphocytic leukemia. Blood 2014; 123: 2139-2147.

76. Oakes C.C., Claus R., Gu L. i wsp. Evolution of DNA methylation is linked to genetic aberrations in chronic lymphocytic leukemia. Cancer Discov. 2014; 4: 348-361.

77. Landau D.A., Clement K., Ziller M.J. i wsp. Locally disordered methylation forms the basis of intratumor methylome variation in chronic lymphocytic leukemia. Cancer Cell 2014; 26: 813-825.

78. Panayiotidis P., Jones D., Ganeshaguru K. i wsp. Human bone marrow stromal cells prevent apoptosis and support the survival of chronic lymphocytic leukemia cells in vitro. Br. J. Haematol. 1996; 92: 97-103.

79. Burger J.A., Tsukada N., Burger M. i wsp. Blood-derived nurse-like cells protect chronic lymphocytic leukemia cells from 
spontaneous apoptosis through stromal cell-derived factor-1. Blood 2000; 96: 2655-2663.

80. Jia L., Clear A., Liu F.T. i wsp. Extracellular HMGB1 promotes differentiation of nurse-like cells in chronic lymphocytic leukemia. Blood 2014; 123: 1709-1719.

81. Binder M., Lechenne B., Ummanni R. i wsp. Stereotypical chronic lymphocytic leukemia B-cell receptors recognize survival promoting antigens on stromal cells. PloS One 2010; 5: e15992.

82. Seiffert M., Schulz A., Ohl S. i wsp. Soluble CD14 is a novel monocyte-derived survival factor for chronic lymphocytic leukemia cells, which is induced by CLL cells in vitro and present at abnormally high levels in vivo. Blood 2010; 116: 4223-4230.

83. Purroy N., Abrisqueta P., Carabia J. i wsp. Co-culture of primary CLL cells with bone marrow mesenchymal cells, CD40 ligand and $\mathrm{CpG}$ ODN promotes proliferation of chemoresistant CLL cells phenotypically comparable to those proliferating in vivo. Oncotarget 2015; 6: 7632-7643.

84. Deaglio S., Vaisitti T., Aydin S. i wsp. CD38 and ZAP-70 are functionally linked and mark CLL cells with high migratory potential. Blood 2007; 110: 4012-4021.

85. Chen L., Huynh L., Apgar J i wsp. ZAP-70 enhances IgM signaling independent of its kinase activity in chronic lymphocytic leukemia. Blood 2008; 111: 2685-2692.

86. Damle R.N., Wasil T., Fais F. i wsp. Ig V gene mutation status and CD38 expression as novel prognostic indicators in chronic lymphocytic leukemia. Blood 1999; 94: 1840-1847.

87. Crespo M., Bosch F., Villamor N. i wsp. ZAP-70 expression as a surrogate for immunoglobulin-variable-region mutations in chronic lymphocytic leukemia. N. Engl. J. Med. 2003; 348: 1764-1775.

88. Marquez M.E., Hernandez-Uzcategui O., Cornejo A. i wsp. Bone marrow stromal mesenchymal cells induce down regulation of CD20 expression on B-CLL: implications for rituximab resistance in CLL. Br. J. Haematol. 2015; 169: 211-218.

89. Ghosh A.K., Secreto C., Boysen J. i wsp. The novel receptor tyrosine kinase Axl is constitutively active in B-cell chronic lymphocytic leukemia and acts as a docking site of nonreceptor kinases: implications for therapy. Blood 2011; 117: 1928-1937.

90. Cols M., Barra C.M., He B. i wsp. Stromal endothelial cells establish a bidirectional crosstalk with chronic lymphocytic leukemia cells through the TNF-related factors BAFF, APRIL, and CD40L. J. Immunol. 2012; 188: 6071-6083.

91. Pedersen I.M., Kitada S., Leoni L.M. i wsp. Protection of CLL B cells by a follicular dendritic cell line is dependent on induction of Mcl-1. Blood 2002; 100: 1795-1801.

92. Granziero L., Circosta P., Scielzo C. i wsp. CD100/Plexin-B1 interactions sustain proliferation and survival of normal and leukemic CD5 + B lymphocytes. Blood 2003; 101: 1962-1969.

93. Brusa D., Serra S., Coscia M. i wsp. The PD-1/PD-L1 axis contributes to T-cell dysfunction in chronic lymphocytic leukemia. Haematologica 2013; 98: 953-963.

94. Ramsay A.G., Johnson A.J., Lee A.M. i wsp. Chronic lymphocytic leukemia $\mathrm{T}$ cells show impaired immunological synapse formation that can be reversed with an immunomodulating drug. J. Clin. Invest. 2008; 118: 2427-2437.

95. Ramsay A.G., Evans R., Kiaii S. i wsp. Chronic lymphocytic leukemia cells induce defective LFA- 1-directed T-cell motility by altering Rho GTPase signaling that is reversible with lenalidomide. Blood 2013; 121: 2704-2714.

96. Motta M., Rassenti L., Shelvin B.J. i wsp. Increased expression of CD152 (CTLA-4) by normal T lymphocytes in untreated patients with B-cell chronic lymphocytic leukemia. Leukemia 2005; 19 : 1788-1793.

97. Zaleska J., Skorka K., Zajac M. i wsp. Specific cytotoxic $\mathrm{T}$-cell immune responses against autoantigens recognized by chronic lymphocytic leukaemia cells. Br. J. Haematol. 2016; 174: 582-590.

98. Burkle A., Niedermeier M., Schmitt-Graff A. i wsp. Overexpression of the CXCR5 chemokine receptor, and its ligand, CXCL13 in B-cell chronic lymphocytic leukemia. Blood 2007; 110: 3316-3325.

99. Bleul C.C., Fuhlbrigge J.M., Casasnovas J.M. i wsp. A highly efficious lymphocyte chemoattractant, stromal cell-derived factor 1 (SDF-1). J. Exp. Med. 1996; 184: 1101-1109.

100. Burger J.A., Tsukada N., Burger M. i wsp. Blood-derived nurse-like cells protect chronic lymphocytic leukemia cells from spontaneous apoptosis through stromal cell-derived factor-1. Blood 2000; 96: 2655-2663.

101. Burger M., Hartmann T., Krome M. i wsp. Small peptide inhibitors of the CXCR4 chemokine receptor (CD184) antagonize the activation, migration, and antiapoptotic responses of CXCL12 in chronic lymphocytic leukemia B cells. Blood 2005; 106; 1824-1830.

102. Mohle R., Failenschmid C., Bautz F. i wsp. Overexpression of the chemokine receptor CXCR4 in B cell chronic lymphocytic leukemia is associated with increased functional response to stromal cell-derived factor-1 (SDF-1). Leukemia 1999; 13: 1954-1959.

103. Decker S., Finter J., Forde A.J. i wsp. PIM kinases are essential for chronic lymphocytic leukemia cell survival (PIM2/3) and CXCR4-mediated microenvironmental interactions (PIM1). Mol. Cancer Ther. 2014; 13: 1231-1245.

104. Mittal A.K., Chaturvedi N.K., Rai K.J. i wsp. Chronic lymphocytic leukemia cells in a lymph node microenvironment depict molecular signature associated with an aggressive disease. Mol. Med. 2014; 20: 290-301.

105. Fecteau J.F., Corral L.G., Ghia E.M. i wsp. Lenalidomide inhibits the proliferation of CLL cells via a cereblon/p21(WAF1/Cip1)-dependent mechanism independent of functional p53. Blood 2014; 124: 1637-1644.

106. Schulz A., Durr C., Zenz T. i wsp. Lenalidomide reduces survival of chronić lymphocytic leukemia cells in primary cocultures by altering the myeloid microenvironment. Blood 2013; 121: 2503-2511.

107. Acebes-Huerta A., Huergo-Zapico L., Gonzalez-Rodriguez A.P. i wsp. Lenalidomide induces immunomodulation in chronic lymphocytic leukemia and enhances antitumor immune responses mediated by NK and CD4 T cells. Biomed. Res. Int. 2014; 2014: 265840.

108. Wu L., Adams M., Carter T. i wsp. Lenalidomide enhances natural killer cell and monocyte-mediated antibody-dependent cellular cytotoxicity of rituximab-treated CD20+ tumor cells. Clin. Cancer Res. 2008; 14: 4650-4657.

109. Chen S.S., Chang B.Y., Chang S. i wsp. BTK inhibition results in impaired CXCR4 chemokine receptor surface expression, signaling and function in chronic lymphocytic leukemia. Leukemia 2016; 30: 833-843.

110. Ponader S., Chen S.S., Buggy J.J. i wsp. The Bruton tyrosine kinase inhibitor PCI-32765 thwarts chronic lymphocytic leukemia cell survival and tissue homing in vitro and in vivo. Blood 2012; 119: 1182-1189.

111. Burger J.A., Peled A. CXCR4 antagonists: targeting the microenvironment in leukemia and other cancers. Leukemia 2009; 23: $43-52$.

112. Stamatopoulos B., Meuleman N., De Bruyn C. i wsp. AMD3100 disrupts the cross-talk between chronic lymphocytic leukemia cells and mesenchymal stromal or nurse-like cell-based microenvironment: pre-clinical evidence for its association with chroni lymphocytic leukemia treatments. Haematologica 2012; 97: 608-615.

113. Hoellenriegel J., Zboralski D., Maasch C. i wsp. The Spiegelmer NOX-A12, a novel CXCL12 inhibitor, interferes with chronić lymphocytic leukemia cell motility and causes chemosensitization. Blood 2014; 123: 1032-1039. 